\title{
IMAGINING THE
}

ELEPHANT

\section{A Biography of Allan MacLeod Cormack}


This page intentionally left blank 
IMAGINING THE ELEPHANT

A Biography of Allan MacLeod Cormack

CHRISTOPHER L VAUGHAN

University of Cape Town, South Africa 


\section{Published by}

Imperial College Press

57 Shelton Street

Covent Garden

London WC2H 9HE

\section{Distributed by}

World Scientific Publishing Co. Pte. Ltd.

5 Toh Tuck Link, Singapore 596224

USA office: 27 Warren Street, Suite 401-402, Hackensack, NJ 07601

UK office: 57 Shelton Street, Covent Garden, London WC2H 9HE

\section{British Library Cataloguing-in-Publication Data}

A catalogue record for this book is available from the British Library.

\section{IMAGINING THE ELEPHANT \\ A Biography of Allan MacLeod Cormack}

Copyright (C) 2008 by Imperial College Press

All rights reserved. This book, or parts thereof, may not be reproduced in any form or by any means, electronic or mechanical, including photocopying, recording or any information storage and retrieval system now known or to be invented, without written permission from the Publisher.

For photocopying of material in this volume, please pay a copying fee through the Copyright Clearance Center, Inc., 222 Rosewood Drive, Danvers, MA 01923, USA. In this case permission to photocopy is not required from the publisher.

ISBN-13 978-1-86094-988-3

ISBN-10 1-86094-988-6

Printed in Singapore. 
For Allan's Family 
This page intentionally left blank 


\section{Contents}

Foreword ix

Preface xi

Acknowledgments $\quad \mathrm{xv}$

1. From John O'Groats to Jo'burg 1

2. On the Slopes of Table Mountain 23

3. Physics and Friends at Cambridge 53

4. Return to the Fairest Cape 91

5. A New Beginning in Boston 111

6. Finding Radon and his Transform 129

7. On the Road to Stockholm 151

8. Citizen of the World 181

9. At Home in Massachusetts 201

$\begin{array}{lll}\text { Appendix A Allan Cormack's Publications } & 217\end{array}$

$\begin{array}{lll}\text { Appendix B } & \text { Nobel Lecture } & 223\end{array}$ 
$\begin{array}{lll}\text { Appendix C } & \text { Presentation of Nobel Prize } & 237\end{array}$

Appendix D Man and Science in the 21st Century 243

$\begin{array}{lll}\text { Appendix E A Teenager's Odyssey } & 249\end{array}$

$\begin{array}{ll}\text { Notes } & 259\end{array}$

$\begin{array}{ll}\text { Figures } & 289\end{array}$

$\begin{array}{ll}\text { Index } & 295\end{array}$ 


\section{Foreword}

I would like to thank Professor Kit Vaughan most sincerely for affording me the great honour of inviting me to write this foreword, especially as I am the least capable of doing it justice.

I also thank him for the excellent research he has undertaken to write this biography in memory of my younger brother Allan MacLeod Cormack and to make it so interesting and instructive. Kit personally travelled around America, England, Scotland and South Africa to speak to Allan's family, friends and colleagues to ensure every detail was correct.

Maybe advanced years afforded me this honour. Old age can sometimes be uncomfortable. The body tells you Old Father Time is rapidly advancing. However, if you go out to meet him, remembering all the good things life has brought, there is no need to feel despondent.

Now, I come back to the birth of my younger brother, Allan, on 23rd February 1924. I was six at the time and was so proud to be sister to this wonderful baby. This pride continued all through our lives together and remembering those years is one of the 'perks' of old age.

I was fortunate to get to know Allan's wife, Barbara, and their three children, Margaret, Jean and Robert. What a talented family they are! We enjoyed their company when visiting America: they could not have been kinder to our family. We were so pleased that they (except Robert) attended our daughter's wedding in Cape Town in 1981.

Here I wish to pay tribute to our Mother who was left a widow in her early 50s when our father died in 1936. She did her utmost to point her three children in the right direction.

Allan had a very astute mind, a wonderful imagination, was full of fun and could be a great tease. When younger this sometimes made me furious but having two brothers I learned to cope with it very easily in later years. 
His love of music remained with him all his days, although he didn't actually play an instrument except for a short time learning the piano. I know that Barbara and her daughter Jean still have season tickets for the Boston Symphony Orchestra.

Allan loved mountaineering as did our son George. He and Allan had a great relationship. According to Allan's family, he and George 'reclimbed' every peak in the Western Cape when George visited the Cormacks in America.

It is most gratifying to know that the proceeds from the sale of this book are to be donated to the Allan Cormack Book Fund at the University of Cape Town. This fund assists needy students wishing to study mathematics and physics in the Faculty of Science. All good wishes to the students who benefit from this fund. May they work hard, play fairly and set their sights on being yet another Nobel Laureate for South Africa.

Amelia McLeod Read Cape Town December 2007 


\title{
Preface
}

\author{
I think I am an Elephant, \\ Behind another Elephant \\ Behind another Elephant who isn't really there ...
}

\section{AA Milne (1927)}

In December 2007, we celebrated the 40th anniversary of the world's first heart transplant, performed by Dr Christiaan Barnard and his team at Groote Schuur Hospital. That event on 3 December 1967 focused international attention on Cape Town and led directly to the recognition that South Africans were capable of conducting world-class research in medical science. As important as Barnard's contribution was, however, I believe that an even more momentous breakthrough in medical science took place ten years earlier at the University of Cape Town. It is the story of computer assisted tomography (or CAT).

In August 1957, Allan MacLeod Cormack returned to the University of Cape Town (UCT) from a year's sabbatical at Harvard University. Although he had accepted a position as an Assistant Professor of Physics at Tufts University in Boston, the Council of UCT required him to return to Cape Town for three months to fulfill his teaching obligations to the university. On Thursday 5 September, in the basement of the physics department, Allan conducted the experiment that would later lead to a seminal publication in the Journal of Applied Physics in 1963. This research, which had been initiated during the first six months of 1956 when Allan worked with Dr James Muir Grieve in the radiology department at Groote Schuur Hos- 
pital, ultimately led to the award of the Nobel Prize for Medicine in 1979, an honour that he shared with Godfrey Hounsfield.

When Allan died on 7 May 1998 I approached his family, both in South Africa and in the USA, with a view to creating a research group at the University of Cape Town that would honour his contributions to science. They readily agreed to my request and in May 2000 we launched the Medical Imaging Research Unit, which has been inspired by the idea that it is possible to conduct world-class research here on the southern tip of the African continent.

This biography on Allan Cormack had its genesis in 2003 when I spent a sabbatical year in Ireland as a Walton Fellow in the Department of Electrical Engineering at University College Dublin. Ernest Walton was Ireland's first (and so far only) Nobel Laureate in the natural sciences, having shared the physics prize with John Cockroft in 1951 for "their pioneer work on the transmutation of atomic nuclei by artificially accelerated atomic particles". In celebration of the centenary of Walton's birth, Vincent McBrierty, an Emeritus Professor of Polymer Physics at Trinity College Dublin, published a biography on Ernest Walton in 2003. That got me thinking. Maybe I could do the same thing for Allan Cormack.

In mid-2004 I approached the family with my idea and again they responded positively. The past three years have been an odyssey for me, as I have travelled from Cape Town to England, visiting Cambridge University, where Allan studied from 1947-1950, to Scotland, where his forebears all originated, to Boston in the USA, where he spent the last 40 years of his life. As you will see from the chapter titles, I have extended this analogy of a journey to the description of Allan's life. It begins in the far north of Scotland, at John O'Groats, stops off at Jo'burg, Table Mountain, Cambridge, Cape Town, Boston and Stockholm, and finishes in Massachusetts.

One of the challenges for any author who completes a book is to select a title that captures the essence of the subject. My challenge was no different. The primary source for Imagining the Elephant comes from the famous Indian legend, captured in the poem by John Godfey Saxe (1816-1887):

It was six men of Indostan,

To learning much inclined,

Who went to see the Elephant

(Though all of them were blind),

That each by observation

Might satisfy his mind. 
Two scientists, in writing about computer tomography, have also alluded to this legend. The first was the late Paul Lauterbur, with whom I exchanged e-mail messages in October 2004. He won the Nobel Prize for Medicine in 2003 for his work in magnetic resonance imaging and he knew Allan Cormack well. He and Allan were on the organising committee for a workshop entitled Techniques of Three-Dimensional Reconstruction that was held at the Brookhaven Laboratory on Long Island, New York in 1974. This is what Lauterbur said to me just over three years ago:

Bob Marr and I toyed briefly with the idea of a follow-up meeting, until we realized that, unusually for scientific meetings, the first one had been so successful that another one was not needed - like the proverbial six blind men, we had all recognized the elephant together.

The other person was George Ellis, a distinguished cosmologist and applied mathematician at the University of Cape Town who wrote an essay on Allan Cormack for a recent book celebrating South Africa's Nobel Laureates. Here's what Ellis wrote:

Consider the age-old example of the elephant. If all you had ever seen of an elephant was a photograph taken from one viewpoint, you would not understand it very well. A series of pictures from a whole variety of vantage points would let you know much more about it - indeed you can build up a 3D image in your mind from an array of $2 \mathrm{D}$ images.

This is the essence of tomography, which is captured in the whimsy of AA Milne's poem about Christopher Robin in Now We Are Six, and quoted at the beginning of this preface. A CAT scanner allows us to uncover the identity of objects that would otherwise be hidden in a traditional 2D X-ray image. When confronted with this challenge 50 years ago, Allan started to think about the problem $a b$ initio. It did not take him long to realise the problem was a mathematical one and so he set about devising a suitable algorithm for solving the problem.

There's another connection between Allan Cormack and the elephant. In December 1945 he and his friends from UCT hiked and climbed in the Cederberg, a mountain range about two hours' drive north of Cape Town. They came across an ancient rock painting, estimated to be two thousand years old, illustrating the Khoisan bushmen and elephants. I know this because I discovered a black and white photograph of the painting in Allan's personal album (see Figure 2.9). While the bushmen and elephants can no 
longer be found in the Cederberg, the stunning painting endures and a photo of it has been used to illustrate the back cover of this book.

I twice heard Allan speak. The first occasion was on Monday 16 March 1981 when he delivered a public lecture at UCT on 'Computer Tomography: Past and Future Portent'. His self-deprecating humour was in evidence, with the audience particularly enjoying his recollection of the lack of interest shown in his original publications and his anecdote of a CAT scanner being used in the search for a skier buried under an avalanche!

The second occasion was on Saturday 16 April 1994 when Allan was a keynote speaker at the Thirteenth Southern Biomedical Engineering Conference in Washington DC, and I was a Professor at the University of Virginia in nearby Charlottesville. He spoke on 'CT Scanning up to the Appearance of the EMI scanner' and again I was struck by his joie de vivre and genuine love of science. So, although I was never formally introduced to Allan MacLeod Cormack, I feel that I have come to know him well during these past three-and-a-half years.

I have written the text in a style and at a level that I hope will be accessible to all readers who have an interest in biography, and not just those scientists who may wonder how it was that a physicist, who solved a mathematical algorithm, came to win the Nobel Prize in Medicine. I trust you will enjoy reading this story about a family man who was often described as a 'modest genius'.

Christopher Leonard (Kit) Vaughan

Cape Town

January 2008 


\section{Acknowledgments}

When I embarked on this journey in mid-2004, I had little idea what the demands would be. Now that I have reached my destination, it is clear that I could not have completed the journey without the advice and enthusiasm of many people. It is a pleasure for me to acknowledge their contributions here.

There were four special people without whom the project could not have happened. These were: Amy Read, Allan's older sister, who was my strongest supporter and whose memory of events and people from over 70 years ago was really quite astonishing; Jean Cormack, Allan's younger daughter, who, shortly after her father's death in May 1998, had the foresight to ask his old friends to write down their recollections of shared experiences; Gareth Vaughan, my son, who tracked down many of Allan's early publications and who edited every chapter; and Margaret Cormack, Allan's older daughter, who provided family details and insights about her father, and who also edited every chapter.

Besides Amy, Jean and Margaret, there were 17 other people whom I interviewed face-to-face. These were: Barbara Cormack, Allan's wife, who generously gave me copies of letters she wrote to her parents from Cambridge University in 1948-49; Robert Cormack, Allan's son, who coauthored a paper with his father while he was still an undergraduate at Harvard and has pursued a career in medical physics; Len Read, Allan's brother-in-law, who provided details of life at the University of Cape Town in the early 1950s; Dorothy and Bob Seavey, Allan's sister- and brotherin-law, who provided perspectives on life at the family retreat in Alton, New Hampshire; Michael de Lisle, one of Allan's climbing companions from 1945-46, who loaned me his logbook from that time; Walter Powrie, Allan's oldest friend from his high school days, who shared Allan's passion for 
climbing; Howard Phillips, who gave me invaluable advice about archives research, and whose book The University of Cape Town: 1918-1948 was a source for some of the anecdotes about Allan's undergraduate years; Andy Koehler, director of the Harvard Cyclotron Laboratory, who provided Allan with friendship and intellectual stimulation for over 30 years; Todd Quinto, Professor of Mathematics at Tufts University, who collaborated with Allan in extending the applications of Radon's transform; Ken Astill, Professor of Mechanical Engineering at Tufts, who remembered Allan as a man with a keen sense of humour who enjoyed being politically incorrect; Kathryn McCarthy, Professor of Physics at Tufts and, when she was Provost, one of Allan's most important supporters; Steve Webb, who shared with me his correspondence with Allan, and whose book From the Watching of Shadows provided key insights into the history of computed tomography; Godfrey Stafford, who overlapped with Allan at UCT and Cambridge and who generously hosted me in his home at Oxford; John Wanklyn, who first met Allan as an undergraduate at UCT in 1942 and was still corresponding with him over 50 years later; Aaron Klug, who studied physics with Allan at UCT and who would also win a Nobel Prize; and Robin Cherry, Professor of Physics at UCT and Allan's first postgraduate student in the early $1950 \mathrm{~s}$.

There were two people whom I interviewed by telephone. These were: Bernard Gordon, who visited Allan in October 1975 to seek his advice on computed tomography and who later developed the instant imaging CAT scanner; and Burton Hallowell, President of Tufts University, who in February 1976 explored the possibility of nominating Allan for the Nobel Prize.

One of the benefits of the modern era has been the internet which enabled me to track down individuals who had information about Allan. The following people answered my questions via e-mail: George Lindsey, one of Allan's fellow Nuclear Nit-Wits, who provided an essay on life at Cambridge University and the Cavendish Laboratory in the post-war years; Colin 'Boot' Butler, a climbing companion of Allan's who also shared his commitment to the teaching of physics; Brenton Stearns, a fellow Assistant Professor of Physics with Allan at Tufts in the late 1950s; David Hennage, an undergraduate physics student, who assisted Allan with his seminal research in the early 1960s; David Ayres, a particle physicist with whom Allan collaborated at Berkeley in 1966-67; Rodney Brooks, who did research with Allan on proton tomography and who also published a review article that drew attention to Allan's research on computer tomography; 
Michael Goitein, who developed his own computer tomography algorithm and tested it with Allan's data, and who later pursued a career in the physics of radiation therapy at Harvard; Bob Marr, who invited Allan to serve on the organising committee for a workshop entitled Techniques of Three-Dimensional Reconstruction in 1974; Paul Lauterbur, whom Allan first met at the workshop and who would later win the Nobel Prize in Medicine for his research on magnetic resonance imaging; Matt Howard, a distinguished and creative neurosurgeon, who, as an undergraduate physics major at Tufts, was inspired by Allan's Nobel Prize; Robert Lewitt, who, as a post-doctoral research fellow in 1977, had the temerity to challenge the mathematics in one of Allan's publications; Marcella Tanona in the Provost's Office at Tufts, who tracked down information on the award of the Hosea Ballou Medal to Allan in 1978; Rose Mary Logue, of University College Dublin, who provided me with the history of Cormac Mac Airt, the most renowned of the ancient kings of Ireland; Brian Warner, Professor of Astronomy at UCT, who supplied key details about Allan's first journal publication in 1945; Maarten de Wit, Professor of Geology at UCT, who provided background information for Allan's second journal publication in 1947; and Cornelis Plug, Professor of Psychology at the University of South Africa, who supplied me with the details of the Jubilee Science Congress held in Cape Town in 1952.

There were then those who gave me something that was critical to the biography. These included: John Juritz, a fellow physicist who studied and worked with Allan at UCT in the 1940s and 1950s, who provided me with old letters and newspaper cuttings; Dick Wilson of Harvard University and a collaborator of Allan's in the 1950s and 1960s, who sent me a copy of A Brief History of the Harvard Cyclotrons; Torgny Greitz, one of Allan's champions who introduced him at the Nobel award ceremony in Stockholm in December 1979, who provided me with the only photographs ever taken of Allan and fellow Laureate Godfrey Hounsfield; Annika Ekdahl of the Nobel Foundation, who sent me material from the Nobel week in December 1979 and gave me permission to reproduce Allan's lecture (see Appendix B); Paul Lagrange, archivist at Rondebosch Boys' High School, who gave me a copy of the book Rondebosch Boys' High and Preparatory Schools 1897-1997; Anne Dunnett of Wick and Margaret MacKay of Edinburgh, who tracked down details of Allan's family all the way back to the late 18th century; Susan Lapides, a photographer who dug out the old negatives of photos she had taken of Allan in October 1979 and gave me permission to reproduce them; Fiona Colbert who gave me the texts St John's College, 
Cambridge and Portrait of a College, and also provided me with archival material on Allan and other Johnians; Gerald Friedland, an emeritus professor of radiology at Stanford, who gave me copies of his correspondence with Allan as well as reprints of papers he had written about Allan; and Leah Ellis of Quest Productions, who sent me a videotape interview and transcript done with Allan for the TV programme called Naked to the Bone.

There were others who provided me with a key service. These included: Cathy Hole of UCT, who transcribed all the interviews; Nazir Karbanee and Charles Harris of UCT, who created the engineering drawings and built the replica of Allan's original CAT scanner (Figure 5.4); Kelvin Fagan of the Cavendish Laboratory in Cambridge, who scanned photographs of equipment and people from the late 1940s; Rich McManus of the National Institutes of Health, who scanned a photograph of Allan and other pioneers of computer tomography; Rik De Decker of UCT, who tracked down a 1946 description of Cormack's Way, a climbing route up Table Mountain opened by Allan; Natsumi Tanimura, a Japanese student studying at UCT, who translated the article about Allan that appeared in a teenager's magazine called Shonen Jump; Annelie O'Hagan, an artist in Cape Town who reproduced the artwork from the Shonen Jump article; Michael Wyeth of Imago-Visual in Cape Town, who designed the cover to this book; and Barbara Elion of One Life Media in Cape Town, who assembled the index.

Not surprisingly, I discovered that a biography is dependent on archival material normally housed in libraries. At Rondebsoch Boys' High School, I was assisted by Peggy Quayle. At the University of Cape Town, those who helped me included Lesley Hart, Stephen Harandien, Sipho Masha and Emily Krige. After Allan died in 1998, his family donated all his papers to the archives section of Tisch Library at Tufts University and it was here that I discovered much of the source material for this book. I spent two productive periods in the archives, in October 2004 and April 2006, and my time there was facilitated by Susanne Belovari, Jo-Ann Michalak and Anne Sauer.

The University of Cape Town generously provided me with financial support and sabbatical leave to work on the biography in 2006. I also acknowledge my editors at Imperial College Press, Lance Sucharov and Katie Lydon, who have been unflagging supporters of this project, despite numerous delays. Finally, I am pleased to recognise my wife Joan who, for over a year, endured my 5:00 am start to the day when I would go and "talk to Allan". Without her understanding, this book would not have seen the light of day! 